\title{
Looking Beyond the Political in Driss Chraïbi's Le Passé simple and Kamel Daoud's Meursault, contre-enquête
}

\author{
Sura Qadiri
}

Recent years have seen an aesthetic turn in postcolonial literary studies. There has been a widespread call for a move away from over-emphasis on the political context and content of postcolonial literary texts, and a greater engagement with their literariness, with their different generic forms and poetic styles. Critics have perceived a problem in the way in which postcolonial texts are identified foremost as products of a very particular political situation, which has meant that more traditional practices of close textual reading have been eschewed in their case. This problematic has been identified and discussed in studies such as Nicholas Harrison's Postcolonial Criticism: History, Theory and the Work of Fiction, in Jane Hiddleston and Patrick Crowley's Postcolonial Poetics: Genre and Form, as well as in Celia Britton's Language and Literary Form in French Caribbean Writing. The inattention to the literariness of postcolonial writing means that texts are read reductively in ways designed to affirm notions about their political contexts. Celia Britton suggests that aesthetic approaches to postcolonial literature are inhibited by 'the urgency of the themes of much of the literature - inequality and the struggle for political liberation'. ${ }^{1}$ These create the sense that 'there is something rather reactionary or dilettante in concentrating solely on their formal and stylistic aspects'. ${ }^{2}$ In his preface to Hiddleston and Crowley's volume, Dominique Combe also expresses the difficulties arising from dealing with literature from a politically charged context by asking the question 'are postcolonial texts bound to disallow a poetic or stylistic

1. Celia Britton, Language and Literary Form in French Caribbean Writing (Liverpool: Liverpool University Press, 2014), p. 3.

2. Britton, Language and Literary Form, p. 3.

IJFrS 17 (2017) 
approach?'. 3 Britton, and other critics calling for an engagement with the literary aspects of postcolonial writing, make the case that a turn towards the aesthetic is not a move away from the political content and context of postcolonial literature. She, along with many others, advocates readings that focus on differentiated forms of interplay between the politics and the aesthetic features of a text. Such readings must stand in the way of mining postcolonial texts for uncomplicated political assertions.

It has been suggested that the attention given to the politics of postcolonial writing has been the cause of constraints being placed on the postcolonial field that have curbed its ability to follow texts in new and unexpected directions. Surveying the critical landscape in 2002, Neil Lazarus describes the discipline as having a routine approach to postcolonial texts, which has meant that 'for most scholars in the postcolonial studies field, literature has served chiefly as a foil, a means of making an argument about cultural experience'. 4 This is echoed more recently by Eli Park Sorenson, whose particular contention is that the field's close alignment with postmodernist theoretical reading paradigms has privileged more experimental styles of postcolonial writing for their politically subversive potential. Such a privileging of the experimental comes at a cost to more conventionally realist styles of writing which are assumed to be more aesthetically restrained and therefore more politically conservative. As a result, 'much postcolonial literature is typically read in a dogmatic and prescriptive way, while the discipline has increasingly become homogenised'.5 Sorenson suggests that the effect does not only determine which texts are more likely to be studied by critics, but that it shapes the postcolonial literary output, with experimental texts more likely to be published in the first place. In addition, then, to the politics of postcoloniality, texts are

3. Patrick Crowley and Jane Hiddleston, eds, Postcolonial Poetics: Genre and Form (Liverpool: Liverpool University Press, 2011), p. viii.

4. Neil Lazarus, 'The Politics of Postcolonial Modernism', The European Legacy, 7.6 (2002), 771-82 (p. 772).

5. Eli Park Sorenson, Postcolonial Studies and the Literary: Theory, Interpretation and the Novel (New York: Palgrave Macmillan, 2010), p. xi. 
bound up with a politics of aesthetics that governs the ways in which they are read, and restricts the possibility of new and creative approaches. For Sorenson and others, the problem is that postcolonial criticism gets stuck in paradigmatic ruts. Britton suggests that the studies compiled in Language and Literary Form manoeuvre themselves away from these by taking on texts on a case by case basis, and avoiding blanket critical positions. Writing about intersections between the formal and the social in each literary text analysed, she asserts that 'the nature of this connection varies considerably between one text and another'. 6

As Combe and Britton point out, the task of looking beyond the political content of postcolonial novels is not a simple one. Attempts at this can be made even more difficult when authors are politically outspoken outside of their literary writing, making it all too easy to read novels as a reinforcement of political statements they make in the press. This study looks at two novels that have strong political overtones, and that are written by politically outspoken authors. Both Driss Chraibi's Le Passé simple (1954) and Kamel Daoud's Meursault, contre-enquête (2013) are narrated in the first person by politically opinionated characters. And both Chraïbi and Daoud have publicly made strong and controversial political assertions about their respective North African countries, Morocco for Chraibi (both before and in the wake of its independence) and contemporary Algeria for Daoud, with an emphasis on the religious zealotry that has brought political turmoil to the country. My rationale in looking at these texts in tandem, in spite of their divergent geo-political and temporal contexts, is to underline the similarities in the critique they face. I will also highlight in each case that the text demonstrates a consciousness of its own literarity, which is juxtaposed with the non-literary strands of discourse that it echoes. My contention is that the strong political views put forward in each of the texts, rather than inviting the reader to detect political ire and to ascribe this to frustrations borne out of coloniality or postcoloniality, actually launch us into wider considerations about literature and the

6. Britton, Language and Literary Form, p. 5. 
dialogic paradigms that should govern the way in which it is read. This study considers the wider reflections on the relationship of the literary to the political to which both novels give rise. Moreover, it gives some focus to the ways in which critique of religion in particular is undercut in both novels by the creative use they make of motifs from religious traditions and narratives. It will suggest that such an engagement with religious heritage is complex, and broadly demonstrative of the fact that literary writing is always multivalent and difficult to reduce to a statement of political, social or religious opinion.

\section{'Le Passé simple'}

Chraïbi's novel, published in 1954 just as Morocco was on the brink of gaining its independence from France, is narrated by an angry adolescent who longs to live as a European, and who expresses contempt for Moroccan culture, which is represented as patriarchal and hypocritical. Nicholas Harrison has discussed at length the way in which the novel entered the political debate both in France and Morocco as an expression of discontent with Moroccan society, leading one French commentator to read it as a 'secret appeal' against decolonization from a French-educated minority in Morocco. ${ }^{7}$ Harrison notes the fact that Chraïbi initially did little to undermine such readings of his text by wading into the debate with comments in the press on how colonialism has brought some benefits to Moroccan society. Though his remarks were later softened, the controversy surrounding his novel led to its banning in Morocco until 1977.

Contrary to how it was read at the time of its publication, it is possible to read the novel as one that does not merely tell the story of discontent with tradition. Criticism on the text has been varied and at times very rich, but with a general emphasis on its subversive cultural

7. Nicholas Harrison, Postcolonial Criticism: History, Theory and the Work of Fiction (Cambridge: Polity Press, 2003), p. 96. 
elements. Ellen McLarney's 'Politics of Le Passé simple ${ }^{8}$ for example, which also sees the furore surrounding the text at the time of its publication as a factor in hindering analytical approaches to it, offers an analysis of resonances between the text and very specific political events in Morocco at the time. It also interprets the motif of father-son tensions as a French-style expression of revolutionary discontent. Part of the text's rebellion, for McLarney, is its upholding of the novel as a secular space that pits itself against religious aspects of society. She identifies the chapter headings, which take their names from the different stages in a chemical experiment (beginning with 'Les Éléments de base' and ending with 'Le Réactif'), as a feature that marks the novel out as an experiment in secular discourse. In contrast with this emphasis on cultural rebellion, looking at Chraïbi's La Mère du printemps, Carine Bourget argues that this particular text, which has been traditionally read as a challenge to Islamic culture in Algeria, designating it as another form of colonialism, is in fact more subtle and ambivalent, and foregrounds a synthesis of Pagan Berber and Islamic Arab identities. ${ }^{9}$ Following on from this, I wish to show in a similar vein that the cultural and religious rebellion of Le Passé simple is more nuanced than it appears. McLarney's reading unearths one particular dimension of the text, and I will suggest that this can be tempered with reference to its more ambivalent engagements with culture and religion. Said Graiouid's reading of the novel as a model for a dialectical public space is particularly useful when thinking about the ambivalence of the text. Graiouid maintains that it creates a 'Rabelaisque world' 10 by constructing 'a realm populated by a cacophony of noises and voices'. 11 This undermines the idea of the hubristically opinionated first-person narrator as a mouthpiece for an

8. Ellen McLarney, 'Politics of Le Passé simple', Journal of North African Studies, 8.2 (2003), 1-18.

9. See Carine Bourget, 'L'Islam syncrétique de Driss Chraïbi', L'Esprit Créateur, 38.1 (1998), 57-68.

10. Said Graiouid, 'We Have Not Buried the Simple Past: The Public Sphere and PostColonial Literature in Morocco', Journal of African Cultural Studies, 20.2 (2008), 14558 (p. 153).

11. Graiouid, 'We Have Not Buried the Simple Past', p. 153. 
opinionated author. Instead, he is designed to elicit 'open confrontation and challenge of ideas and opinions rather than "hypocritical" or homogenizing consensus'. ${ }^{12}$ Building on this interpretation, I will extend some of Graiouid's ideas on the relationship between public space and the imaginary to the relationship between the individual and the imaginary. I will suggest that, just as the imaginary brings dialogism to public discourse, the novel posits the emergence of an individual's sense of imagination as a personal form of maturity. This makes Le Passé simple a coming-of-age novel, about a young man who struggles to make sense of a world that he sees as full of selfcontradictory absolutes. Driss the narrator tells the story of the emergence of his own imagination, and of how this helps him to negotiate the world, and to move away from seeing it in absolute terms. Driss gives an account of the events that led him to become a writer, and to note down his own story, which is what readers have before them. This account is represented as a process of fictionalization, with emphasis placed throughout the text on how the narrative is constructed. It is a process that allows Driss to gain control over his unbridled behaviour, as he moves away from being a character who vents his frustrations by candidly telling others what he thinks of them, to someone who is able to think in one way and act in another, and to document this gap between thought and behaviour through the construction of narrative.

Control over his responses to the world is accompanied by an increase in control over his narrative style and the language that he uses. The juxtaposition in the novel of language that seems angry, clumsy and unconsidered with narrative moments that reflect greater consideration of the poetic effects of language helps to forge a connection between maturity and the crafting of a story. There are instances in the text where Driss's language is peppered with poetic rhymes and assonances that hint at an aspiration to make sense of things through poetic distance. For example, 'un uléma des

12. Graiouid, 'We Have Not Buried the Simple Past', p. 152. 
Karawwiyine avait allumé un cierge en cire vierge'13, and '[j]e cousais rues et ruelles. Idées et visions. J'accusais chaque passant'. ${ }^{14}$ Phrases containing rich imagery and enhanced aural qualities betray an endeavour to master narrative, to prevent language from spilling out angrily in all directions. This is language that has been thought through, and that contrasts with knee-jerk diatribes addressed at other characters. Carefully crafted phrases also seem to synthesize images and ideas that might contrast in reality. In particular, the image of an 'uléma' lighting a candle presents us with an Islamic scholar partaking in a Christian tradition. Candles are lit in churches, not in mosques. Whilst the overall image is incongruous if translated into reality, it works as a linguistic construct, and so emphasizes the potential of the language of the imagination as a discursive space that does not follow the rules and logic of everyday life, and of social and political reality.

The book explores intergenerational relations and shifts in identity at the dawn of decolonization. Driss aspires to a high degree of Frenchness. He skips fasts in Ramadan, defecting to the European neighbourhoods in town, where his fair complexion and western style of dress allow him to blend in with the Europeans and eat, drink, and above all smoke without recrimination. He takes great pains to perfect his Western style of dress, ironing his shirts (a task that his father cannot understand), and stealing money from his father in order to buy socks. His father has made no provision for these, deeming them unnecessary. Though Driss goes to a fee-paying school and has a room fully equipped with books, a telescope, and other materials to help him with his education, his father still keeps him in a tight financial stranglehold, withholding funds for the merest trifle if he does not see the point in it. The text opens with the family waiting to break their fast at the end of a day in Ramadan. Though the call to prayer has sounded, announcing the end of the fast, Driss's father has insisted that the family continue to fast as they wait for Driss's missing brother, Camel, who has gone out drinking in flagrant disregard for the holy month.

13. Driss Chraïbi, Le Passé simple (Paris: Denoël, 1954), p. 90.

14. Chraïbi, Le Passé simple, p. 78. 
Outside, a beggar is calling up to the family for some food. The scene brings to the fore a threefold repression. There is the religious repression imposed through fasting. The hardship of this is prolonged on the father's orders, which adds the force of patriarchal repression. The hungry beggar is symptomatic of a wider social repression. Driss writes with due frustration about his father's authoritarian ways and about religious hypocrisy. And though he gives food to beggars sometimes, he does not muse much on any social injustice that may have caused their situation. His anger is not, then, one that is politically radical or socially engaged. It is more a sign of immaturity, a form of teenage rebellion.

Driss himself seems aware of his shortcomings as a figure representing any sort of ideological position. He is often humorously self-deprecating in a way that makes light of his potential as a serious social commentator. Reflecting on the small imperfections in his western costume, he says: 'Imaginez-vous un Nègre du jour au lendemain blanchi mais dont, par omission ou méchanceté du sort, le nez est resté noir.' ${ }^{15}$ Driss's analogy suggests that he situates himself between African and European identities in descending order, but also unflatteringly caricatures him as a mimicker of European civilization. And whilst he prefaces the analogy with 'même enfant, j'ai toujours eu la rage de la justice', ${ }^{16}$ the idea that being prevented from completing his European image is a miscarriage of justice is merely symptomatic of an adolescent feeling that all in life is unfair. There is something too parodic about the teenage angst of Driss to make him a reliable mouthpiece for Chraïbi's political opinions.

Driss, then, is a teenage rebel, one who is on the brink of discovering his imagination and the ways in which it can allow him to make sense of the world. Harrison's insistence that the novel communicates more than the protagonist's disgust with Moroccan society hinges on its recurring reference to the Ligne Mince. The text is not explicit about what this is, but it seems to mark out a mental

15. Chraïbi, Le Passé simple, p.18.

16. Chraïbi, Le Passé simple, p.18. 
space to which Driss retreats when wishing to escape his surroundings. Harrison qualifies it as something that 'propel[s] the reader lurchingly from the fictional-real to the irreducibly textual and figurative'. ${ }^{17} \mathrm{It}$ seems to signify a form of stepping outside of Driss's reality, and moving into a space of consciousness that allows him to digest it, that is akin to the nausée of Sartre's Roquentin. Sartre's existentialist hero famously suffers from waves of nausea that overcome him unexpectedly, and that place him at a contemplative distance from events in his daily life. These constitute a visceral manifestation of Roquentin's philosophical doubts about existence. Driss has much in common with Roquentin, including a sense of detachment from society and a scorn for the bourgeois classes. Roquentin also reflects on his experience of the real material world and considers the relation of the world to writing. This resonates with the understanding Driss develops of writing about his own experiences as a buffer between himself and the world. Roquentin remarks that 'il faut choisir: vivre ou raconter' ${ }^{\text {' }}$ because 'quand on vit, il n'arrive rien'. ${ }^{19}$ Writing moulds the flow of life into a rhetorical structure with temporal dimensions. This sense of structure is absent from the experience of life itself. For Driss, this distance between life and narrative offers him a means of taking control of his life. The intertextual resonance also helps to situate Le Passé simple on a literary map, thereby emphasizing its literariness.

The Ligne Mince, then, is a fine line that allows him to cross the threshold between the real and an imagined space, offering him some form of escape or relief from reality. Upon seeing it towards the end of the first chapter, during which his father prolongs his fast, he says 'et c'est la Ligne Mince, par quoi j'échappe'. ${ }^{20}$ The Ligne Mince offers itself as a distraction when he closes his eyes to try to sleep: '[C]'est d'abord comme un fil de toile d'araignée, un fil si mince, si impalpable qu'il en est irréel. Ce fil est une lettre, un chiffre ou une ligne brisée.' ${ }^{21}$

\footnotetext{
17. Harrison, Postcolonial Criticism, p. 97.

18. Jean-Paul Sartre, La Nausée (Paris: Gallimard, 1938; repr. 2013), p. 64.

19. Sartre, La Nausée, p. 64.

20. Chraïbi, Le Passé simple, p. 64.

21. Chraïbi, Le Passé simple, p. 65.
} 
The line that marks out the threshold of Driss's imagination is thus associated with alphabetical letters and other characters, consolidating the relationship between the imagination and writing in the novel. The line goes on to take different forms in Driss's mind, having 'l'allure d'un piston de moteur, d'une hélice d'avion, d'une trajectoire de fusée', ${ }^{22}$ all of which suggest motion and the possibility of escape. It then acquires 'une sorte de son', which emerges as 'un sifflement de balle'. ${ }^{23}$ The reference to a bullet is evocative of Driss's family name, Ferdi, which means both 'individual' and 'pistol' in Arabic, making it an oblique reference to Driss's own imagination and the subversive power this wields. The line then recedes, becoming once again 'pareille à un fil de toile d'araignée'. ${ }^{24}$ The image of a line here, in a chapter that dramatizes events connected to the fast, is religiously apt, because the start and end of the fast are traditionally marked by the visibility of lines or threads. The Quran describes the timings of the fast thus: 'eat and drink until the white thread becomes distinct to you from the black thread of the dawn'. ${ }^{25}$ The image of the spider's web has a multivalent place in Islamic lore. On the one hand, it features in an incident where the Prophet and his companion hid from their enemies in a cave. According to the narrative, they are saved because a spider promptly spins its web across the mouth of the cave, leaving pursuers to imagine that they could not have entered the cave without disturbing the web, and so opting not to search for them inside. The Quran also uses the spider's web to symbolize that which is weak and ineffectual: 'The likeness of those who choose other allies than Allah is as the likeness of the spider when she makes to herself a house, and the frailest of all houses is the spider's house, if but they knew. ${ }^{26}$ The Ligne Mince thus

22. Chraïbi, Le Passé simple, p. 64.

23. Chraïbi, Le Passé simple, p. 64.

24. Chraïbi, Le Passé simple, p. 65.

25. The Majestic Quran: An English Rendition of its Meanings, ed. by Abdal Hakim Murad, Mostafa Badawi, Uthman Hutchinson, trans. by Ali Özek and others (London: Nawawi Foundation, 2000), p. 29 (2. 187).

26. The Majestic Quran, p. 401 (29. 41). Paul Bowles makes reference to the Quranic motif in his novel about the struggle for Moroccan Independence, The Spider's House, first published in 1955. 
ambivalently becomes doubly evocative of a religious symbol of refuge as well as of subversion and of challenge to authority. This ambiguity signals a nuanced relationship with cultural and religious motifs in the novel that is more complex than the critique and rebellion expressed through Driss's professed attitude towards society. The suggestion of rebellion is tempered by the more positive religious connotations of the spider's web, and by the implicit rhythmic overlap between the crossing of the Ligne Mince and the fasting day. This softens Driss's position as an unequivocal critic of society and religion.

At the start of the novel, the Ligne Mince itself fills the horizons of Driss's imagination. The fact that it is a line makes it a boundary or threshold, and so it is the boundary that looms large on the horizon, not what lies beyond it. In some ways, the story focuses on how Driss comes to be able to cross the Ligne Mince, moving deeper into the realm of the imagination, and how this enables him to reflect on reality and to provide a response to it that is not angry and immediate. The turning point comes when he is cast out of his home after a dispute with his father. He is turned away from the homes of friends who have been warned by his father not to take him in, before taking refuge in a church, where he seeks the advice of a priest, Blot. This encounter may be contrasted with his earlier trip to his mother's native town in order to seek the prayers of a religious man for help with his father's business. In both cases, Driss is drawn to the corporeal functions and mannerisms of the religious men. Driss takes an instant dislike to the spiritual figure of Kettani in his mother's home town who, Driss judges, eats with too much gusto and has too strong a libidinal drive, with a disquieting penchant for young boys. Driss's contemplation of the priest at the church is different. It draws him out of himself, as he observes Blot's mannerisms closely and wonders: 'quelle histoire d'amour, quel concours de circonstances, quel aboutissement de mesures coercitives l'ont relégué au plan de consolateurs d'âmes, lui que je sens, que je sais destiné uniquement à la satisfaction des corps' ${ }^{27}$ The passage marks possibly the first instance in the novel where Driss

27. Chraïbi, Le Passé simple, p. 193. 
truly contemplates another person in a way that is not clouded by his own judgements and preoccupations. The fact that the encounter with the priest displaces Driss's own problems from his mind reinforces the idea that Driss has really been distracted from himself. It is to Driss's imagination that the priest appeals, as he longs to know his 'histoire d'amour', and so Driss's imagination is truly awakened through this encounter with the priest.

Though it takes place in a church, and as such may be politically problematic, the encounter is not a spiritual epiphany. The fact that Driss takes an interest in the priest's bodily features and mannerisms and notes that he is someone who is destined to bring relief to bodies as opposed to souls suggests that he has taken a human interest in him. He does not put faith in him as a spiritual healer. Unlike anyone Driss has met before, the priest listens, and does not speak hastily. Upon hearing Driss's problem, he says: 'Évidemment, c'est un problème assez difficile à résoudre. A trois titres. D'abord parce qu'il est mal posé; secundo parce que je ne l'ai pas vécu et par conséquent, tertio, que je le considère avec mes yeux d'Européen et de prêtre. ${ }^{28}$ The priest puts forward a tripartite logic which suggests a measured and structured critical response. This contrasts with models of speech that Driss has seen in other social figures of authority, notably his father and Kettani, both of whom can be loquacious, and freely pass judgements on subjects beyond the scope of their understanding. Often Driss's frustration is at the hypocrisy of such figures, whose moralizing utterances jar with their own habits. Driss's stern father, for example, who posits himself as moral guardian of the family, has a secret concubine and illegitimate children. The lack of separation between Driss's inner thoughts and his volatile speech and actions suggests an inability to match this social habit of separating declared principles and clandestine personal behaviours. Hypocrisy seems the only social model available for separating inward and outward realities. The priest seems to offer an alternative, which involves listening closely and

28. Chraïbi, Le Passé simple, p. 193. 
affirming his own inability to comment as someone who does not inhabit Driss's reality.

The effect of this encounter on Driss is that he is suddenly able, at last, to call on his imagination. Rather than announcing the approach of the Ligne Mince, he crosses it unannounced, beginning to see the distorting effects of his imagination on his surroundings. He describes, for example, the way in which the talking priest's lips appear to detach themselves from his face, shrinking and then growing to fill his visual field. Driss does not hear what they are saying, only indistinct whispers. Then, his visual field shuts down altogether, as he announces that: 'Ce champ s'obscurcit, s'éteignit soudain et je ne fus plus qu'une main.' 29 This hand comes to rest itself on a shoulder in church: 'Une épaule! je sais. Un fleuve de cheveux blonds et qui fleure l'adolescence à peine déféquée houle à quelques centimètres de ma face.' ${ }^{30}$ This speech is not uttered out loud, but is directed to the anonymous girl on whose shoulder his hand is resting. She is the 'petite fille' to whom he now addresses his thoughts. His inner voice seems to have found a direction in which it may be channelled. It is no longer merely an angry diatribe which flows directly out of him towards the object of his thoughts. There is now an imagined listener. This is a narrative voice emerging. He notes that his friend Roche has advised him to write a novel, and that this is now what he is beginning to do:

Parfait! a conclu Roche. Garde cela en toi, bien ancré en ta mémoire, cultives-en chaque fait, chaque incidence. Plus tard, lorsque ton vocabulaire comportera quelque 8000 mots, et lorsque le recul aura suffisamment aiguisé cette révolte, tu pourras en faire un roman.

Un roman. Un roman, entends-tu? Dont les éléments seraient: une histoire de thés, un bref séjour, à Fès, la mort d'Hamid, ma révolte. Si je pouvais encore rire, petite fille! $!^{31}$

29. Chraïbi, Le Passé simple, p. 194.

30. Chraïbi, Le Passé simple, p.194.

31. Chraïbi, Le Passé simple, p.198. 
Driss begins to think in terms of this narrative. He says 'voilà... voilà. Le personnage va se réintégrer dans le quatrième chapitre... ${ }^{32}$ to which the girl replies 'qu'est-ce que c'est que cette mixture d'essai et de roman, ces termes agglutinés? ${ }^{33}$ Driss has found the voice of his imagination, which gives him a critical distance from his own story. $\mathrm{He}$ has also found the critical voice that does not challenge him personally, but challenges the narrative that he has constructed out of personal events, thus suggesting that the narrative acts as a buffer, displacing him as the direct object of scrutiny and censure. The fact that he has concentrated himself into a hand, a hand that writes, means that he is able to efface himself through his writing.

In many ways, then, Le Passé simple is a coming-of-age story that charts the emergence of Driss's inner space of imagination and of his ability to revisualize society at a distance through his writing. Unlike his angry social voice, the narrative voice of his writing is more perceptive and considered. As an individual, he is now able to distinguish between that which should be projected and that which should be internalized in a given social situation. This is something that the development of his imagination has helped him to comprehend. For example, just before he leaves for France, as his father offers him advice, he thinks to himself, 'je l'ai souverainement possédé. Il n'en saura jamais rien' ${ }^{34}$ Where his father was once able to see through him, to know when he was brooding, this is no longer the case. His anger and irreverence remain a feature of his character, but are now better contained. His writing is a space of outpouring of his now functioning imagination. All is featured in his writing, both his thinking and what he chooses to express of it, making the literary an all-encompassing third space, a space that lays bare the mechanisms involved in reflecting on the world and responding to it. Literary writing is more than testimony. It is more than a record of events and attitudes. We are neither only privy to what Driss thinks nor only to what he says. We see both in a form of dialectical continuum. Moreover, the fact that

32. Chraïbi, Le Passé simple, p. 202.

33. Chraïbi, Le Passé simple, p. 203.

34. Chraïbi, Le Passé simple, p. 271. 
Roche advises Driss to wait until he has '8000' words of vocabulary suggests that writing a 'roman' is primarily an aesthetic process, during which words take primacy over events. The prime object of the novel is to craft a story out of words, and the preoccupation with words and how to arrange them is more absorbing than the plot elements themselves. The fact that the first chapter of the novel is headed 'Les éléments de base', seen through Roche's recommendation that Driss's narrative be centred on a group of key 'éléments', transforms the social and the political themes of the first chapter into narrative-building foundations. These are now subsumed by a logic of the piecing together of fictional narrative, completing the sense of paradigmatic shift that arises when politics is discussed in a literary context. The chemical process which, as I discuss with reference to McLarney above, is evoked through the chapter headings, works as an analogy for the way that narrative transforms a variety of discursive strands into something that no longer resembles the original. References to politics, society and religion within the context of the novel are therefore no longer simply reducible to those strands of discursive practice.

\section{'Meursault, contre-enquête'}

Like Le Passé simple, Daoud's novel, from the outset, engages with political themes related to colonialism and its aftermath. Its first-person narrator, Haroun, is not only critical of colonial racism, but is also highly critical of the public face of religion in contemporary Algeria. In addition, the novel also raises questions about the politics of the production of the postcolonial novel by positing itself as a response to Camus's L'Étranger. His text seems to 'speak back' to Camus's (whilst also drawing on Camus's La Chute), specifically addressing its problematic elision of the identity of the 'Arab' killed by Meursault. Narrated from the point of view of his brother, the novel tells the story of the Arab, focusing particularly on the difficulties faced by his family after he is killed, and narrating his brother's killing of a Frenchman in 
a way that may be read as an inversion of Camus's story. On the face of it, the novel follows the well-documented tradition of responding to a metropolitan classic, a practice that is discussed in The Empire Writes Back, ${ }^{35}$ and that has been deemed problematic because it can mean that postcolonial writers speak second, and reinforce the primacy and the centrality of the metropolitan text. They are read as localized variations on something that is original and authentic though, as I will argue, this is not what Daoud's text does.

Lia Brozgal asserts that the text subverts many expectations of it as a response to Camus. She maintains, on the one hand, that even though 'Daoud has installed his text not only in the double bind of the postcolonial remake, but also in the particular snarl of issues that haunt critical discourse on the Maghrebi novel', it 'negotiates its way out of this double bind' ${ }^{36}$ through a variety of subtle discursive manoeuvres. Similarly, for Valérie K. Orlando, the engagement with Camus in novels that, like Daoud's, have a contemporary setting, transposes Camus's writing as an analytical tool which may be useful in a context other than its own. It does not automatically signify a political challenge to Camus. ${ }^{37}$ Like Le Passé simple, Meursault evokes, from the outset, a defined discursive position, bolstered by the views of an opinionated narrator. But just as Driss's opinionated rage may be read as a generator of dialogism rather than the novel's permeation by a singular voice, the seeming literary binarism of Meursault's engagement with Camus's novel is, on closer inspection, a subversion of binarism. Speaking about Meursault at Yale University, ${ }^{38}$ Daoud likens L'Étranger to Robinson Crusoe which, he suggests, is a sort of

35. See Bill Ashcroft, Gareth Griffiths, and Helen Tiffin, eds, The Empire Writes Back: Theory and Practice in Postcolonial Literatures (London: Routledge, 2002).

36. Lia Brozgal, 'The Critical Pulse of the Contre-enquête: Kamel Daoud on the Maghrebi Novel in French', Contemporary French and Francophone Studies, 20.1 (2016), 37-46 (p. 38).

37. See Valérie K. Orlando, 'Conversation with Camus as Foil, Foe and Fantasy in Contemporary Writing by Algerian Authors of French Expression', Journal of North African Studies, 20.5 (2015), 865-83.

38. See 'Kamel Daoud: The Yale Lecture' $<$ https://www.youtube.com/watch? $=$ oF5kWeLG Rv8> [accessed 12 July 2016] 
prototypical colonial novel. The fact that the Arab is shot on a beach and reference is made to surrounding water, for example, is evocative of the island on which Crusoe is marooned, whilst the nameless Arab is like the islander Friday. Both have their identities wiped blank by a colonizing presence. The connection between Crusoe and L'Étranger is very loose and speculative, but the fact that Daoud sees Defoe's novel as a literary precursor to Camus's suggests that he does not see L'Etranger as an originary text in its own right against which his own pits itself. Both are placed within a broader framework, encompassing innumerable responses to and reworkings of Crusoe (for example Michel Tournier's Vendredi ou les limbes du Pacifique, which retells the story with an emphasis on sexuality). Within this framework there is a sense of flow between literary texts. Themes and motifs are carried forward intertextually with reference to their own contexts. This literary interaction is more dialogic than binary. It resonates with Theo D'Haen's discussion of 'world literature' which, he argues, is now premised on non-hierarchised engagements with literary 'nodal points'. ${ }^{39}$ These are texts like Crusoe which are repeatedly revisited and rewritten in a variety of social and linguistic contexts. Their status as 'nodal points' is not inherent but retrospective, coming from the attention bestowed on them by other writers. Not all of these rewritings are necessarily anti-colonial (D'Haen cites V.S. Naipaul as an example of a postcolonial writer whose adaptations reiterate colonial positions in their politics), and so the idea of a political binary relationship is unsettled. I will argue that, in the case of Meursault, the binarism of the novel's relationship to L'Étranger is undermined in particular through the recurring motif of scriptural pairs of brothers, whose relationships symbolize different types of human encounter and how these generate stories. This subtle engagement with scriptural motifs, as well as undermining binary structures, also suggests a more thoughtful negotiation of scripture than is expressed by the vocally

39. Theo D'Haen, 'World Literature, Postcolonial Politics, French-Caribbean Literature', in Littératures francophones et politique, ed. by Jean Bessière (Paris: Karthala, 2009), pp. 63-76 (p. 65). 
irreligious Haroun, once again moving the novel beyond its politically opinionated overtones.

As I suggest above, Daoud's Meursault evokes entrenched literary and political positions only so it can challenge these. The narrator is the Arab's brother, Haroun (Aaron), and the text in many ways openly inverts the circumstances of the murder of the Arab, to whom the name Moussa (Moses) is given. The text opens with an inversion of the famous opening line of L'Étranger, with the narrator declaring: 'Aujourd'hui, M'ma est encore vivante.' ${ }^{40}$ Haroun then continues to address his first-person narrative to an anonymous French reader/listener in a bar, sometimes referring to his book in the hands of the reader, and at other times giving the impression that the narrator and reader are seated together as the narrator tells his story. Haroun narrates the difficulties of growing up in the shadow of his brother's death, and with a mother consumed by rancour, little able to give him any love or attention. He and his mother live in a house left derelict after the departure of its colonial dwellers in the wake of Algerian independence. At this time, Haroun kills a Frenchman in the garden of their home by the light of the moon at two in the morning, in a direct inversion of the killing of the Arab at two in the afternoon in dazzling sunlight in L'Étranger. Also, in opposition to Camus's text, the Frenchman is given a name, Joseph. As with Meursault, the investigation into the murder committed by Haroun does not focus on the crime itself, but on tangential features of the protagonist's life. In Haroun's case, the preoccupation is with why he chooses to kill a Frenchman days after Algerian independence, having not involved himself in combat during the War, when it was legitimate to kill Frenchmen. And, in opposition to Meursault, who is condemned for his crime, Haroun is set free by the authorities. The novel thus posits itself, in the first instance, as a textual opposite to L'Étranger. Beyond this, it communicates a sense of disappointment with the political ambience in an Algeria that has now been independent for some time. By making a desolate bar the setting for an encounter between the now

40. Kamel Daoud, Meursault, contre-enquête (Arles: Actes Sud, 2014), p. 11. 
elderly narrator and a French reader/listener, the novel suggests a sense of social dejection and isolation. Haroun often expresses feelings of distaste for his home town, Oran, which he compares to a tired old prostitute, as well as for the religious culture around him.

Yet, as Brozgal points out, Meursault is in many ways like L'Étranger, and not an inversion of it. One indicator of this is the resonance between the names Moussa and Meursault, which suggests similarity rather than opposition. Alice Kaplan suggests, furthermore, that 'by the end of the novel, Haroun's rage against Meursault has transformed itself into empathy and a near-brotherly identification'. ${ }^{4}$ Haroun's own mission statement of rectifying the harm done to his brother through anonymity ('on ne tue pas facilement un homme quand il a un prénom' ' ${ }^{42}$ is progressively undermined in the novel because, as Brozgal suggests, the specificity of the name Moussa is slowly eroded. She cites the fact that Haroun imagines the waiter at the bar to be called Moussa too, and even uses the name 'synecdochally' 43 at times to refer to all Arabs, making statements like 'on va juste regarder tous les autres Moussa de ce bouge', ${ }^{44}$ and 'Moussa est un Arabe que l'on peut remplacer par mille autres'. ${ }^{45}$ The Arab, then, does not get the story he has been denied in L'Etranger, and so Meursault, contre-enquête does not fulfil the brief of responding to Camus's text in a way that supplements it by giving voice to a silent Arab. This is reinforced by the fact that the novel does not return to the temporal setting of Camus's text, offering us a version narrated by the Arab himself, but offers us an account that is obliquely retrospective. For Brozgal, the novel produces a 'carefully constructed impasse' that 'does not deliver Moussa's story but rather a story of narrative impossibility', ${ }^{46}$ the effect of which is to invite careful reading both of itself and of

41. Alice Kaplan, Looking for the Outsider: Albert Camus and the Life of Literary Classic (Chicago: University of Chicago Press, 2016), p. 209.

42. Daoud, Meursault, contre-enquête, p. 62.

43. Brozgal, 'The Critical Pulse of the Contre-enquête', p. 39.

44. Daoud, Meursault, contre-enquête, p. 35.

45. Daoud, Meursault, contre-enquête, p. 58.

46. Brozgal, 'The Critical Pulse of the Contre-enquête', p. 43. 
L'Etranger. The companion in the bar is an academic scholar, and as such the novel seems to invite a change in scholarly reading practice.

Further to highlighting and troubling the discursive double bind that it faces, Meursault offers practical ways in which it can be read other than as a text that hinges on the idea of reclaiming postcolonial subjectivity or speaking back. It imagines a literary paradigm in which texts can respond to one another without this being reduced to an ethical repartee determined by postcolonial sensibilities. It establishes instead a sense of narrative movement that, though it may be propelled or informed by political positions, ultimately transcends specific situations. The novel does this in particular through its use of the motif of scriptural pairs of brothers, whose relationships represent both harmony and discord. The names Haroun and Moussa are evocative of the advocacy and cooperation between the Prophet Moses and his brother Aaron as it is narrated in the Quran. ${ }^{47}$ When informed of his role as a prophet to the tribe of Israel, Moses makes the following request of God: 'My brother Aaron is more eloquent than me of speech. So send him with me as a helper to confirm me. For I fear that they will give the lie to me. ${ }^{48}$ The Quranic Moses is often represented as a large man with great physical strength (having himself once killed a man through accidental over-exertion of force), but without his brother's eloquence. On account of his supplication, Haroun is also made a prophet of God, and they come to work as a pair. Daoud's brawny Arab, Moussa, and his articulate brother Haroun clearly evoke this scriptural pairing. Moreover, in a bid to invert the killing of a nameless Arab in L'Étranger, Haroun reveals that the name of his French victim is Joseph, another Quranic prophet known for his relationship with his brothers, and in particular with his younger brother Benjamin who,

47. Jane Hiddleston sees in the name Haroun a gesture towards the caliph in the Arabian Nights, Harun Al Rashid, and makes a connection between Daoud's text and the historical intersection between politics and story in Islamic culture. See Jane Hiddleston, Writing After Postcolonialism: Francophone North African Literature in Transition (London: Bloomsbury, 2017), pp. 162-63.

48. The Majestic Quran, p. 389 (28. 34). 
unlike his other brothers, shares the same mother. ${ }^{49}$ Both Joseph and Benjamin are persecuted by their jealous older brothers, with Joseph ultimately succeeding in neutralizing their scorn (thus helping his brother as well as himself). There is therefore potentially an aggrieved younger brother beyond the text who will take up the next narrative against Haroun, making this a self-perpetuating paradigm.

In addition to the pairs of allied scriptural brothers alluded to in the text, there are repeat references to Cain and Abel. In the first instance, the comparison is applied by Haroun to himself and Moussa, suggesting that he has often desired the death of his already dead brother, who has become a sort of textual effigy: 'Peut-être est-ce moi, Caïn, qui ai tué mon frère! J'ai tant de fois souhaité tuer Moussa après sa mort, pour me débarrasser de son cadavre, pour retrouver la tendresse perdue de M'ma.' 50 The comparison also begins to draw the Algerian Haroun into an antagonistic brotherly relationship with his French audience. There is a sense of crossover here as he goes on to argue:

Tu saisirais mieux ma version des faits si tu acceptes l'idée que cette histoire ressemble à un récit des origines: Caïn est venu ici pour construire des villes et des routes, domestiquer des gens, sols et racines. Zoudj était le parent pauvre, allongé au soleil dans la pose paresseuse qu'on lui suppose, il ne possédait rien, même pas un troupeau de moutons qui puisse susciter la convoitise ou motive le meurtre. D'une certaine manière, ton Caïn a tué mon frère. ${ }^{51}$

49. Haroun makes an oblique connection between Joseph the victim and Joseph the scriptural prophet where he says his grave is as deep as 'le puits du prophète Youssef'. Daoud, Meursault, contre-enquête, p. 58.

50. Daoud, Meursault, contre-enquête, p. 57.

51. Daoud, Meursault, contre-enquête, p. 67. References to the story of Cain and Abel as analogous to that of colonialism are a recurrent literary motif. Chraïbi refers to a racialized version of the story in an epigraph to Le Passé simple, which suggests that both brothers were black until Abel turned white with horror at his own crime. Camus's Le Premier Homme (Paris: Gallimard, 1994) also compares colonial acts of interracial violence to the scriptural act of fratricide. The narrator Jacques, upon witnessing the aftermath of a roadside attack, recalls the doctor Veillard's remark that 'on remonte au premier criminel, 
'Zoudj', a term meaning 'double'52 is used throughout the novel to designate Moussa as the silent partner. The scriptural analogy is used here to condemn colonialism in strong terms, suggesting that the killing of the Arab is even more morally reprehensible than that of Abel, since there was no obvious material gain involved, making it all the more gratuitous. What is interesting is that the beginning of the story here is posited as textual. It has its roots in a 'récit des origines' which forms part of a common narrative heritage. Haroun's own story relates to it through permutation and subversion. The story precedes the agents here, and is merely propagated and reworked through alternating dynamics of antagonism and alliance. Daoud thus uses the motif of scriptural pairs of brothers to illustrate a dynamic of narrative motion. These pairs are used to stage particular socio-political contexts and to show how a particular story is adapted within that context. Stories resonate with a narrative precedent, but always reproduce it in a differentiated way. Daoud could have produced a story that delivers the voice of the Arab more directly (through a retelling of events from his perspective, for example). The fact that he leaps forward to a different temporal setting, and tells a digested story that is focalized through a younger brother, speaks not of a logic of impasse or stalemate, where one account comes to complete or rebut the other, placing them at loggerheads, but of a passing on of the story. In this regard, the text is not 'speaking back', but 'speaking on'. The scriptural references reinforce this structure. The pairs of scriptural brothers evoke both the Quran and the Bible, both of which draw on many of the same historical narratives offering different angles and emphases. Moreover, many of them were prophets, ultimately speaking of God, but in different times to different peoples, thus representing the fluidity of the same narrative. Haroun's final self-characterization as 'El Merssoul' is an Arabization of Meursault, but also comes from the same route in

vous savez, il s'appelait Caïn, et depuis c'est la guerre, les hommes sont affreux, surtout sous le soleil féroce' (p. 209).

52. See Hans Wehr, A Dictionary of Modern Written Arabic (New York: Snowball Publishing, 2012), p. 385. 
Arabic as 'al rassoul', meaning prophet, thus cementing his role as a form of prophet narrator. ${ }^{53}$ The parallel here does not convey spiritual sentiment, but sets up a certain narrative paradigm. A scriptural prophet is the conveyer of a message that precedes them and that will continue after their time. The message is, as such, timeless. But the context in which they utter it gives it a strong geo-political dimension that defines the way in which it is told. By drawing Camus's text into a narrative of political accountability and redress, Daoud does not tether it to its place of geo-political issue, over-localizing its value. Instead, the latter's text enacts a form of narrative relay that demonstrates how world events move a narrative on through time and space. Haroun states that once he has killed the Frenchman, his mother begins to age naturally, and wrinkles like a page. ${ }^{54}$ The metaphor merges the textual and the material, suggesting that they move to propel each other forward. Ultimately, Daoud's novel does not politicize the literary by morally questioning Camus. It creates moral questions of its own in its revisiting of Camus's novel (does, for example, the naming of Haroun's French victim make his a more ethical killing than that of Meursault?). The political becomes a vehicle for literary creation in Daoud's novel, and in this way, is subservient to it. This inverts the idea of the literary as a vehicle for political opinion which hampers readings of postcolonial fiction.

Both Chraïbi and Daoud, then, turn what at first seems to be a political voice into a literary one. Chraïbi's Driss works towards finding his own literary voice, which allows him to process and synthesize the conflicting realities of his life. This voice represents a form of maturity that allows him to see the world in less absolute terms. The raw personal and political anger of Driss the protagonist is channelled away from people and into writing, where it becomes indirect and diffuse. This is not a mere depiction of a youth caught up in a very specific conflict of cultures, but a more general comment on the literary and its uses, both personally and socially. Literary practice

53. See Hans Wehr, A Dictionary of Modern Written Arabic, p. 339.

54. See Daoud, Meursault, contre-enquête, p. 89. 
is shown to signify maturity and an ability to make sense of the world. Similarly, Daoud's text maps Camus's story and Haroun's supplement to it onto narratives from a shared but differentiated scriptural heritage that demonstrates the ways in which stories are passed on and reinterpreted through time. This is not only the reality of postcolonial fiction, which is traditionally seen to respond to colonial attitudes and narratives. It is the reality of all narrative. In this way, both texts offer themselves as broader explorations of the effects of the literary not only within their own contexts, but well beyond.

Pembroke College, University of Cambridge 